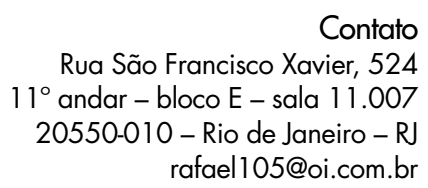

Contato

Rua São Francisco Xavier, 524

$11^{\circ}$ andar - bloco E - sala 11.007

20550-010 - Rio de Janeiro - R

rafael105@oi.com.br

\section{MODERNISMO E CONTEXTO POLÍTICO: A RECEPÇÃO DA ARTE MODERNA NO CORREIO DA MANHÃ $(1924-1937)^{*}$}

\section{Rafael Cardoso*}

Universidade do Estado do Rio de Janeiro

\title{
Resumo
}

O presente artigo examina a discussão de "arte moderna" no jornal Correio da Manhã, um dos principais diários brasileiros do século 20, entre os anos de 1924 e 1937. Ao seguir detalhada e sistematicamente a cobertura dada pelo jornal a esse tema, constata-se que o assunto era percebido à época de modo bastante distinto da narrativa ascendente construída pela historiografia posterior. O artigo dedica atenção particular à correlação entre arte moderna e o contexto político imediato, focando nas conexões do meio artístico com debates ideológicos vigentes. Evidencia-se a constituição gradativa de um discurso associando arte moderna a comunismo, que atinge seu ápice com uma campanha anticomunista inflamada no momento logo após a sublevação militar de novembro de 1935. É considerado e revisto o papel de atores importantes no percurso histórico da arte moderna no Brasil, de diversas tendências - com destaque para Graça Aranha, Oswald de Andrade, Mário de Andrade, José Oiticica e Carlos Maul. O propósito da pesquisa é fornecer dados originais que complementem a visão consagrada do movimento modernista, a qual evidencia tendência a privilegiar fontes produzidas pelos próprios atores do movimento e seus herdeiros, assim como fontes exclusivas às artes plásticas. A compreensão alargada da recepção da arte moderna torna possível avaliar com mais nuance e complexidade seu impacto histórico.

\section{Palavras-chave}

Modernismo - artes plásticas - anticomunismo.

* O autor agradece a Eduardo Jardim por ler e comentar uma versão anterior deste artigo.

** PhD em História da Arte pelo Courtauld Institute of Art, University of London. Professor colaborador do Programa de Pós-Graduação em Artes do Instituto de Artes. 
rev. hist. (São Paulo), n. 172, p. 335-365, jan.-jun., 2015 http://dx.doi.org/10.11606/issn.2316-9141.rh.2015.98695

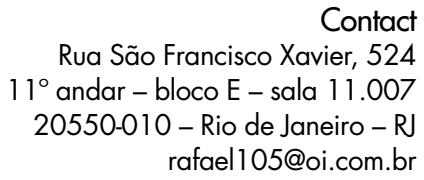

Contact

Rua São Francisco Xavier, 524

$11^{\circ}$ andar - bloco E - sala 11.007

20550-010 - Rio de Janeiro - R

rafael105@oi.com.br

\section{MODERNISM AND POLITICAL CONTEXT: THE RECEPTION OF MODERN ART IN THE NEWSPAPER CORREIO DA MANHÃ (1924-1937)}

\section{Rafael Cardoso}

Universidade do Estado do Rio de Janeiro

\begin{abstract}
The present article examines the debates surrounding "modern art" in the newspaper Correio da Manhã, one of the leading Brazilian dailies of the 20th century, between the years 1924 and 1937. A systematic and detailed reading of its coverage demonstrates that the subject was perceived in its time in a manner markedly distinct from the triumphal narrative enshrined subsequently by the historical literature. The article devotes particular attention to the correlations between modern art and the immediate political context, focusing on links between the art world and prevailing ideological debates. Noteworthy is the gradual ascendancy of discourses linking modern art to Communism, culminating in a fiery anti-Communist campaign in the wake of the military uprising of November 1935. The roles played by diverse agents influential in the history of Brazilian modernism are considered and reviewed; in particular: Graça Aranha, Oswald de Andrade, Mário de Andrade, José Oiticica and Carlos Maul. The aim of the present research is to provide primary data complementing the established view of the modernist movement in Brazil, which has traditionally accorded privileged status to sources produced by the modernists themselves and their heirs, as well as sources linked exclusively to the visual arts. A broader understanding of the contemporary reception of modern art provides a subtler and more problematized insight into its historical impact.
\end{abstract}

\title{
Keywords
}

Modernism - visual arts - anti-Communism. 
Perdura no senso comum sobre arte moderna no Brasil uma narrativa triunfal que conduz da Semana de Arte Moderna, em 1922, até a Exposição Geral de Belas Artes de 1931, perfazendo uma trajetória de São Paulo para o Rio de Janeiro em que o movimento modernista se alastra e se consolida em nível nacional. O caminho é pontuado por alguns marcadores - dentre os quais os manifestos redigidos por Oswald de Andrade $(1924,1928)$ e os deslocamentos realizados por Mário de Andrade pelo interior do país, em especial a famosa "caravana modernista" para as cidades históricas de Minas Gerais (1924), mas também suas viagens pela Amazônia (1927) e pelo Nordeste (1928-29). A trajetória narrada guarda paralelos significativos com a história do tenentismo: a Semana de 1922 como precursora imediata do episódio dos 18 do Forte; os manifestos como eco do movimento armado paulista de 5 de julho de 1924; as viagens por sertões e arraiais, matas e praias como uma Coluna Prestes em miniatura; o Salão de 1931 como reflexo do momento em que os cavalos foram amarrados ao obelisco da avenida Rio Branco. Tanto esta percepção existiu que a imprensa contemporânea não hesitou em apelidar esse certame de "Salão dos Tenentes" ou "Salão Revolucionário", alcunha que se firmou. ${ }^{1}$ Em 1944, Oswald de Andrade retomou de modo explícito a conexão com o tenentismo na palestra "O caminho percorrido", recapitulando a trajetória do movimento modernista desde 1922: “Nunca se poderá desligar a Semana de Arte Moderna que se produziu em fevereiro, do levante do forte de Copacabana que se verificou em julho, no mesmo ano". ${ }^{2}$

Ao longo dos anos, esse paralelismo presumido entre as "revoluções" política e estética naturalizou-se ao ponto de ser raramente posto em questão. No entanto, "o caminho percorrido" não é tão linear, ou sem percalços, quanto quis a estratégia retórica de Oswald de Andrade. Do Salão de 1931, a narrativa costuma saltar bruscamente para a construção do edifício do Ministério da Educação e Saúde, entre 1936 e 1945, tomando o palácio Capanema como metáfora para a constituição de uma cultura nacional e moderna sob a proteção do Estado forte. Para muitos herdeiros do movimento, a expansão para o âmbito oficial por meio da arquitetura representaria uma concretização, literal, das aspirações literárias e artísticas que motivaram a Semana e que foram frustradas com as revezes sofridas em 1931. Ao supri-

${ }^{1}$ GOUVÊA VIEIRA, Lúcia. Salão de 1931: Marco da revelação da arte moderna no Brasil. Rio de Janeiro: Funarte, 1984, p. 122-123.

2 ANDRADE, Oswald de. Ponta de lança. São Paulo: Globo, 1991, p. 109-118. (Obras completas de Oswald de Andrade) 
mir conflitos e estabelecer uma teleologia que une o movimento de 1922 às transformações ocorridas após o fim do Estado Novo, em 1945, essa narrativa possibilita glosar quase todo o período conturbado da era Vargas. É evidente que ela mascara as muitas contradições presentes nas discussões culturais da época, devidamente assinaladas por estudiosos do período. ${ }^{3}$ Se a sociedade brasileira como um todo foi palco de conflitos violentos nos anos $1920 \mathrm{e}$ 1930, por que haveria de ser diferente no campo das artes?

Um dos motivos por trás dessa visão simplista do triunfo da arte moderna é a tendência de historiar os acontecimentos unicamente a partir das fontes especializadas em artes plásticas ou arquitetura. Prevalece ainda o costume de tratar os escritos críticos e teóricos sobre arte como matéria à parte, o que acaba por reproduzir, dentro do âmbito dos estudos históricos, a postura pouco justificável de firmar uma separação artificial entre arte e sociedade. Outro motivo para a leitura distorcida dos fatos reside na tendência de privilegiar as fontes produzidas pelos próprios atores do movimento modernista. Por razões evidentes, é impossível obter uma visão equilibrada do contexto de recepção do modernismo sem levar em consideração a maneira em que o movimento foi visto pelo restante da sociedade. Mais uma tendência problemática da historiografia tem sido a de dar prioridade às fontes geradas em São Paulo em detrimento das do restante do país e, em especial, do Rio de Janeiro. Não seria possível compreender a opinião pública do país - e, por extensão, o quadro de mentalidades da época - sem levar em consideração a forte preponderância do então Distrito Federal como centro para a difusão de ideias e chancela de projetos. Ao examinar fontes que não sejam específicas nem ao meio artístico, nem ao modernismo, nem ao ambiente paulista, o quadro que aparece se desvia marcadamente dessa narrativa ascendente.

O presente artigo busca reconstituir a recepção da arte moderna em sua época, traçando uma relação com o contexto político imediato. Com essa finalidade, enfoca-se aqui a discussão sobre arte moderna ocorrida no jornal Correio da Manhã, um dos principais diários do Rio de Janeiro entre 1924 e 1937, período durante o qual o assunto ocupou as páginas desse órgão

\footnotetext{
Ver, entre outros, LISSOVSKY, Maurício \& MORAES DE SÁ, Paulo Sérgio. Colunas da educação: A construção do Ministério da Educação e Saúde. Rio de Janeiro: Iphan/MinC \& CPDOC/FGV, 1996; LORENZO, Helena Carvalho de E COSTA, Wilma Peres da (org.). A década de 1920 e as origens do Brasil moderno. São Paulo: Ed. Unesp, 1997; SCHWARTZMAN, Simon; BOMENY, Helena Maria Bousquet; COSTA, Vanda Maria Ribeiro. Tempos de Capanema. São Paulo: Paz e Terra / FGV, 2000; WILLIAMS, Daryle. Culture wars in Brazil: the first Vargas regime, 1930-1945. Durham: Duke University Press, 2001.
} 
com vivacidade intensa. É relevante para a presente discussão o fato de que Oswald de Andrade tenha escolhido justamente o Correio da Manhã - e não um jornal de São Paulo ou uma revista modernista - como veículo para a publicação de seu "Manifesto da poesia Pau Brasil", verdadeiro marco inicial do movimento em termos de sua percepção por um público nacional. ${ }^{4}$ Não é, portanto, gratuita a ação de privilegiar o Correio da Manhã num balanço da recepção do modernismo, já que um dos atores principais do movimento paulista o escolheu como instrumento para fazer ressoar suas ideias. No que tange à escolha das datas limite, dois fatos são dignos de nota: primeiro, que as referências a "arte moderna" são reduzidíssimas antes de 1924, sendo desprezíveis mesmo no período de 1922, quando da ocorrência da Semana, e, em segundo lugar, que o assunto desaparece quase por completo após 1937, possivelmente em função do clima de censura e ameaças em torno do golpe do Estado Novo. Após treze anos de debate constante e acalorado, o Correio da Manhã impõe uma moratória sobre o tema que perdura, com poucas e estratégicas exceções, por dois anos, entre meados de 1937 e meados de 1939.

Cabe ainda uma palavra sobre as justificativas metodológicas para a escolha do Correio da Manhã, em detrimento de outros órgãos da imprensa. ${ }^{5}$ Pelo grande número de jornais editados à época, seria impossível proceder à compilação sistemática de todos. Optou-se aqui por enfocar um único órgão, com o intuito de registrar as nuances de transformação do discurso dentro de uma linha editorial determinada. Por ser um dos jornais mais lidos e respeitados do país, de conhecida independência para os padrões jornalísticos da época, o Correio da Manhã é representativo de parcela importante da opinião pública contemporânea. Trata-se de um "jornalão", no melhor estilo das folhas liberais do período, de alinhamento político levemente conservador e oposicionista de modo pragmático. Apoiou a Revolução de 1930, por necessidade, mas manteve postura crítica a Vargas, sendo inclusive o veículo da famosa entrevista de José Américo de Almeida que contribuiu

\footnotetext{
4 ANDRADE, Oswald de. Manifesto da poesia Pau Brasil, Correio da Manhã. Rio de Janeiro, 18/03/1924, p. 5. O manifesto aparece na página "Letras \& Artes" do jornal, junto com uma reportagem, não assinada, sobre "Minas no moderno movimento literário" e um texto de Oswaldo Orico intitulado, sugestivamente, "A viuvez da Academia".

5 Sobre a história do jornal, ver BARBOSA, Marialva. História cultural da imprensa. Brasil - 1900-2000. Rio de Janeiro: Mauad X, 2007, p. 83-91; ANDRADE, Jeferson de. Um jornal assassinado: A última batalha do Correio da Manhã. Rio de Janeiro: José Olympio, 1991. O Correio da Manhã está disponibilizado integralmente, entre as datas de 1901 e 1974, na Hemeroteca Digital Brasileira, projeto da Fundação Biblioteca Nacional http://hemerotecadigital.bn.br/acervo-digital/correio-manha/089842.
} 
para sua deposição em 1945. Por suas posições frequentemente combativas, sofreu ameaças e fechamentos em várias ocasiões, antes e depois da era Vargas, assim como prisões de seus dirigentes. Seu diretor M. Paulo Filho, que assumiu a direção do jornal em 1928, era nascido Paulo Bittencourt, filho do fundador Edmundo Bittencourt. Seu redator-chefe, Costa Rego, foi considerado um dos jornalistas mais influentes do Brasil e era ativo na política, exercendo mandatos legislativos em esfera nacional, como deputado e senador por Alagoas, e chegando a governador desse estado. Sob seu comando, o Correio da Manhã mantinha uma postura de equilíbrio ostensivo, evidenciando cuidados para não ferir as suscetibilidades de nenhuma categoria social ou instituição importante. Tanto isto é verdade que, em sua cobertura do tema "arte moderna", o jornal demonstra nítida preocupação em abrir suas páginas para os dois lados: partidários e opositores, que comparecem com assiduidade ao debate.

\section{O triunfo das novas ideias, 1924-1928}

O assunto "arte moderna" não motivava maior interesse no Correio da Manhã antes de 1924. O termo era empregado de modo habitual, mas principalmente para referir o cinema como meio e técnica. Já no início dos anos 1920, é comum encontrar referências à "arte moderna do cinema" ou elogios a filmes realizados com "arte moderna". Com menor frequência, o termo era empregado para falar sobre música, de modo análogo, distinguindo estilos e procedimentos contemporâneos dos antigos. Em proporção ainda menor, é possível encontrar "arte moderna" como um termo de encômio - e de valor publicitário crescente - associado a atividades como teatro, móveis, moda, perfumaria e até tinturaria e cabeleireiros. Para o uso jornalístico corriqueiro da época, realizar uma atividade com "arte moderna" equivalia a executá-la com os processos mais avançados e de acordo com padrões de gosto atualizados.

Uma das primeiras menções à arte moderna em sua acepção plena, consagrada pelo uso posterior, ocorreu no final de 1923, em artigo de autoria de Di Cavalcanti (escrito e ilustrado por ele) em que o artista comenta as novidades do Salão de Outono, de Paris, elogiando o alinhamento desse evento "com a modernidade". ${ }^{6}$ Muito embora fosse um dos principais integrantes da Semana de 1922, de memória ainda recente, Di não faz nenhuma menção a

${ }_{6}$ DI CAVALCANTI. De Paris. Correio da Manhã, Rio de Janeiro, 09/12/1923, p. 2. 
ela nesse texto. Poucos dias depois, aparece em posição de destaque - na primeira página do jornal - artigo de Oswald de Andrade intitulado "Vantagens do caos brasileiro". Um pequeno preâmbulo apresenta o escritor aos leitores, identificando seu pertencimento a "um grupo interessante de artistas brasileiros", o qual inclui Di Cavalcanti, Tarsila do Amaral e Victor Brecheret, que se encontram juntos em Paris:

Oswald de Andrade é um dos porta-vozes desse grupo de gente nova que quer acabar com as nossas tradições artísticas, medíocres e estrangeiradas, para adaptar à arte nacional, por meio de fórmulas novas e audaciosas, tudo o que o Brasil possui de belo e forte, original e nobre. É tempo de olharmos a nossa natureza e aproveitarmos o tesouro que nos oferecem nossas camadas populares. ${ }^{7}$

Assim surge Oswald para o público do jornal, situado como apologista do "nacional", contra as "tradições estrangeiradas", uma posição capaz de angariar simpatia na esteira do Centenário da Independência. O Correio da Manhã acolhe o escritor com guarida excepcional, apelidando-o de "evangelista do Brás e do Montparnasse". Oswald não perde a ocasião para pregar seu evangelho, disparando ataques retóricos contra a Academia e apontando a oportunidade de abraçar os aspectos "primitivos" da cultura brasileira no exato momento em que, segundo ele, a Europa estaria engajada em processo de descobrir e se render à América.

Antes mesmo da publicação do "Manifesto da poesia Pau Brasil", Oswald de Andrade já ampliava seu espaço no Correio da Manhã. Em 19 de fevereiro de 1924, a página "Letras $\mathcal{E}$ Artes" traz uma entrevista com o escritor para discutir "a questão estética do momento". Perguntado se acredita no "triunfo das novas ideias", Oswald se pronuncia: "É indiscutível como o triunfo do telefone, do avião, do automóvel. Há aliás toda uma correspondência viva e direta entre as artes de hoje e o nosso tempo tão diverso dos tempos idos". ${ }^{8} \mathrm{O}$ grupo de "novos" de São Paulo se manteve em evidência na página de "Letras $\mathcal{E}$ Artes" durante o primeiro semestre de 1924, tendo como ponto alto a publicação do manifesto em março. ${ }^{9}$ Contudo, sua presença ficou restrita a essa seção do jornal. A discussão sobre arte moderna só retornou às primeiras páginas do Correio da Manhã na sequência da conferência do escritor Graça Aranha, intitulada "O espírito moderno", pronunciada em 19 de junho, mar-

\footnotetext{
7 ANDRADE, Oswald de. Vantagens do caos brasileiro. Correio da Manhã , Rio de Janeiro, 12/12/1923, p. 1.

8 Era nova, arte nova. Correio da Manhã, Rio de Janeiro, 19/02/1924, p. 5.

9 A tendência nacionalista dos "novos" de S. Paulo. Correio da Manhã, Rio de Janeiro, 11/06/1924, p. 5.
} 
co do seu processo de rompimento com a Academia Brasileira de Letras. Na sequência desse fato, o jornal abriu espaço para Oswald de Andrade se manifestar, desta vez em artigo de duas colunas na segunda página, intitulado "Modernismo atrasado". Sentindo-se atingido por uma menção elíptica aos "escritores que no Brasil procuram dar de nossa vida a impressão de selvageria", tachados por Graça Aranha de "pedantes literários", Oswald contra-ataca:

Graça Aranha é dos mais perigosos fenômenos de cultura que uma nação analfabeta pode desejar. Leu mais duas linhas que os outros, apanhou três ideias além das de uso corrente e faquirizado por uma hipnose interior, crédulo e ingênuo, quer impor à outrance os seus últimos conhecimentos, quase sempre confusos e caóticos. ${ }^{10}$

Com a verve e a virulência habituais, Oswald repele "a falsa e errada ofensiva de Graça Aranha" e reclama para si a prioridade nas conquistas modernizantes, "por que eu tenho me empenhado há alguns anos no Brasil e na Europa". O tom do texto é de indignação, não tanto pela defesa das ideias modernistas por parte de Graça Aranha, tachada de confusa, mas pelo fato de que sua posição, no seio da Academia e da capital federal, lhe garantiu de imediato uma repercussão negada aos acontecimentos de 1922 e, por extensão, reforçou a percepção pública de sua liderança do movimento.

Após o pronunciamento de Graça Aranha, o assunto da "arte moderna" passa a figurar com maior frequência no Correio da Manhã, emancipando-se definitivamente da página literária. A partir de então, qualquer notícia sobre exposições tende a referir o posicionamento do artista com relação ao modernismo, destacando o fato de ser "arte moderna" ou de ter "sentido moderno" sua obra - casos de Alberto da Veiga Guignard, em 1924, e Nicola de Garo, em 1925. ${ }^{11}$ A coluna de variedades "A Vida Social" faz menção ao assunto com regularidade, sugerindo que arte moderna já era percebida como modismo elegante. Sobretudo nessa época, o jornal veicula notas, matérias e entrevistas que buscam situar "arte moderna" como fenômeno de importância na Europa, especialmente em Paris. ${ }^{12}$ Adivinha-se, nas entrelinhas, uma preo-

\footnotetext{
${ }^{10}$ ANDRADE, Oswald de. Modernismo atrasado. Correio da Manhã, Rio de Janeiro, 25/06/1924, p. 2. A frase original, que motivou a resposta de Oswald, está reproduzida em: GRAÇA ARANHA. Espírito moderno. São Paulo: Companhia Graphico-Editora Monteiro Lobato, 1925, p. 43.

${ }^{11}$ Uma interessante exposição de desenhos. Correio da Manhã, Rio de Janeiro, 12/07/1924, p. 3; Da arte moderna. Correio da Manhã, Rio de Janeiro, 11/06/1925, A Vida Social, p. 8.

${ }^{12}$ VASCONCELLOS, Irene de. A exposição das Tuileries. Correio da Manhã, Rio de Janeiro, 07/08/1924, p. 2; Notícias de Paris. Correio da Manhã, Rio de Janeiro, 03/06/1925, p. 6; Letras e artes na França. Correio da Manhã, Rio de Janeiro, 10/06/1925, A Vida Social, p. 3.
} 
cupação em justificar a seriedade emprestada ao tema. Em contraposição, os setores mais frívolos do jornal continuam a tratar arte moderna como "exotismo" e "maluquice", conforme entrega o colunista "Rob" em junho de 1925.13

A partir de meados de 1925, evidencia-se nova preocupação nas páginas do Correio da Manhã: a de explicar o sentido da arte moderna para seu público leitor. Um longo artigo assinado pelo crítico José Clemente, "Sobre o modernismo", publicado por ocasião de banquete oferecido a Graça Aranha, explicita tendências como futurismo, cubismo, dadaísmo, expressionismo, surrealismo, entre outras, e maneja sua discussão com habilidade e conhecimento. A postura do crítico é de defesa do modernismo, conclamando Graça Aranha a não desfalecer em seus esforços. ${ }^{14}$ Pouco tempo depois, aparecem dois artigos importados da Europa: o primeiro sobre "A evolução da 'arte moderna'" (com o termo entre aspas, repara-se), de autoria do crítico francês Ivanhoe Rambosson, um dos fundadores do Salão de Outono de Paris, explicando a evolução do conceito com relação às artes decorativas, e o segundo de autoria de Georges Loukomski, artista e historiador da arte russo, ativo na França, sobre "A arte na Rússia revolucionária". ${ }^{15}$ Esse último texto representa a primeira associação, feita nas páginas do Correio da Manhã, entre arte moderna e comunismo, aspecto que viria a tomar importância decisiva em anos posteriores.

A visita de F. T. Marinetti ao Brasil, em maio de 1926, forneceu o segundo grande ímpeto à cobertura do Correio da Manhã. Em outra rara ocorrência de extravasar as páginas internas ou do suplemento de domingo, a discussão de arte moderna ganhou três colunas inteiras (do total de nove) da capa da edição de 16 de maio. O artigo traz o discurso de Graça Aranha, que recepcionou o líder futurista no Teatro Lírico do Rio de Janeiro, assim como a fala do próprio Marinetti, e as reações do público. Quem ocupa o maior espaço é Graça Aranha, cuja declaração, "A Academia brasileira morre na indiferença do país e no desprezo dos escritores", é elevada à posição de sub-lead da matéria. ${ }^{16}$ Nota-se que o interesse jornalístico está dirigido principalmente a dois fatos: a presença do famoso visitante estrangeiro e os ataques à Acade-

\footnotetext{
${ }^{15}$ As mulheres fatais. Correio da Manhã, Rio de Janeiro, 13/06/1925, A Vida Social, p. 5.

${ }^{14}$ CLEMENTE, José. Sobre o modernismo. Correio da Manhã, Rio de Janeiro, 19/06/1925, p. 4.

${ }^{15}$ RAMBESSON [sic], Ivanhoe. A evolução da "arte moderna". Correio da Manhã, Rio de Janeiro, 02/08/1925, p. 6; LOUKOMSKI, Georges. A arte na Rússia revolucionária. Correio da Manhã, Rio de Janeiro, 27/09/1925, suplemento, p. 1.

${ }^{16}$ Para saudar a Marinetti. Correio da Manhã, Rio de Janeiro, 16/05/1926, p. 1.
} 
rev. hist. (São Paulo), n. 172, p. 335-365, jan.-jun., 2015 http://dx.doi.org/10.11606/issn.2316-9141.rh.2015.98695
Rafael Cardoso

Modernismo e contexto político: a recepç̃õo da arte moderna no Correio da Manhã (1924-1937)

mia Brasileira de Letras. Para chegar à primeira página do jornal, a discussão da arte moderna precisa ainda estar revestida de tons de polêmica literária.

Somente em julho de 1927, a Semana de Arte Moderna ganha uma segunda menção nas páginas do Correio da Manhã. Uma resenha do livro $O$ homem da galeria, de René Thiollier - um dos principais organizadores da Semana e participante da viagem modernista às cidades coloniais de Minas - lembra o papel do autor como secretário da comissão que promoveu, em São Paulo, “a célebre semana de arte moderna a qual, como se sabe, alimentou durante muitos dias a veia humorística dos cronistas, sendo objeto de constantes pilhérias e irreverentes chacotas". Essa lembrança não se refere, certamente, à cobertura do Correio da Manhã, em cujas páginas a Semana sequer emplacou uma nota em 1922, muito menos uma crônica. A resenha faz questão ainda de dissociar Thiollier "dessa arte moderna", explicando seu envolvimento no evento como tendo ocorrido apenas com o intuito de auxiliar Graça Aranha, identificado como o "patrono da tal semana". ${ }^{17} \mathrm{O}$ tom do resenhista com relação ao evento de 1922 beira o desdém. O texto ecoa ainda a percepção, equivocada ou não, da liderança do escritor maranhense no movimento. ${ }^{18}$

Tem continuidade, no restante da década de 1920 e início dos anos 1930, o esforço do Correio da Manhã para educar seus leitores sobre arte moderna por meio de artigos geralmente favoráveis ou, no mínimo, que contemporizem críticas às distorções e bizarrices percebidas, passando por explicações que relacionam tendências estéticas à evolução social, científica e mesmo de ordem espiritual. ${ }^{19}$ Uma das contribuições mais significativas, nesse sentido, são as colunas sobre casa e arquitetura assinadas pelo arquiteto J. Cordei-

\footnotetext{
${ }_{17}$ MAIA, Carlos da. O homem da galeria. Correio da Manhã, Rio de Janeiro, 16/07/1927, p. 2. A Semana de Arte Moderna foi, de fato, assunto de vivo interesse na imprensa paulistana; ver FABRIS, Annateresa. O futurismo paulista: Hipóteses para o estudo da chegada da vanguarda no Brasil. São Paulo: Perspectiva, 1994, p. 139-179.

${ }^{18}$ Essa identificação era tida amplamente entre os artistas modernos nordestinos - até mesmo o apóstolo modernista em Pernambuco, Joaquim Inojosa, cujo famoso panfleto de divulgação do modernismo, O Brasil brasileiro (1925), trata sistematicamente Graça Aranha como fundador e líder do movimento. INOJOSA, Joaquim. A arte moderna \& $O$ brasil brasileiro (edição comemorativa do cinquentenário). Rio de Janeiro: Editora Meio-Dia, 1977. Cf. GOUVÊA VIEIRA, op. cit., p. 16.

${ }^{19}$ PRADO, Rachel. Da arte antiga à arte moderna. Correio da Manhã, Rio de Janeiro, 30/06/1929, p. 12. Esse ímpeto pedagógico não se restringe à matéria do jornal, mas encontra expressão também em conferências e cursos anunciados em suas páginas - inclusive de Fléxa Ribeiro, professor ligado à Escola Nacional de Belas Artes. Os cursos e conferências da Associação Brasileira de Educação no Departamento do Rio de Janeiro. Correio da Manhã, Rio de Janeiro, 20/12/1929, p. 4. Sobre Fléxa Ribeiro, ver AGUIAR, Vinicius (org.). Fléxa Ribeiro: Trechos d'O
} 
ro de Azeredo, que surgem no suplemento dominical do jornal em 1929 e são publicadas em ritmo crescente até 1934, quando começam a aparecer sob a rubrica "A Nossa Casa". Quase sempre explícitas em sua advocacia da "arte moderna", as colunas de Cordeiro de Azeredo demonstram um entusiasmo pioneiro por concreto armado e formas despojadas como elementos da construção. São bastante cândidas ainda em seu relato dos avanços do "regime da arte moderna" no Brasil e no reconhecimento da existência de "refratários à corrente modernista". ${ }^{20}$ Pelas colunas do arquiteto, já é possível entrever os primeiros sinais da tempestade que iria se armar após 1935.

\section{O apaixonamento de opiniões, 1925-1931}

Em meio a esse esforço do jornal para transmitir a seus leitores o sentido exato da arte moderna, chama a atenção um "Panorama do modernismo brasileiro", publicado em janeiro de 1929, sem autoria identificada, porém assinalado como "comunicado especial da 'Kosmos'". ${ }^{21} \mathrm{O}$ texto anuncia a intenção de serenar o que descreve como "apaixonamento de opiniões (...) que origina a desorientação do grande público". Após considerações iniciais sobre o modo inadequado pelo qual o modernismo foi introduzido no Brasil, ele procede a um mapeamento criterioso do campo, grupo por grupo, região por região, e identifica com acuidade filiações e tendências. Esse panorama precioso abrange até mesmo aqueles identificados como "valores esparsos, abandonados no marasmo das províncias" ou esquecidos injustamente nas

imaginário (Pretextos de arte). 19\&20. Rio de Janeiro: Dezenovevinte, v. 6, n. 4, 2011, snp, http:// www.dezenovevinte.net/artigos_imprensa/flexaribeiro01.htm.

${ }^{20}$ AZEREDO, J. Cordeiro de. A arte moderna e os atuais acabamentos. Correio da Manhã, Rio de Janeiro, 29/09/1929, suplemento, p. 2; Idem. Agência do Banco do Brasil de Teófilo Otoni. Correio da Manhã, Rio de Janeiro, 19/04/1931, suplemento, p. 2; Ibidem. O estilo moderno pelo Brasil. Correio da Manhã, Rio de Janeiro, 14/08/1932 suplemento, p. 4; Ibidem. A arte moderna e os atuais acabamentos. Correio da Manhã, Rio de Janeiro, 29/09/1929, suplemento, p. 2; Ibidem. No regime da arte moderna. Correio da Manhã, Rio de Janeiro, 20/01/1935, suplemento, A Nossa Casa, p. 9. Sobre a atuação de Cordeiro de Azeredo como arquiteto e editor da revista $A$ Casa, ver CORREIA, Telma de Barros. Art déco e indústria - Brasil, décadas de 1930 e 1940. Anais do Museu Paulista. São Paulo: Museu Paulista, v. 16, n. 2, 2008, snp, http://www.scielo.br/scielo. php?pid=S0101-47142008000200003Escript=sci_arttext\#nt19; e PINTO JUNIOR, Rafael Alves. Modernidade antes dos modernistas: $\mathrm{O}$ interesse dos periódicos pelo espaço arquitetônico no Brasil. Arquitextos. São Paulo: Vitruvius, v. 13, n. 153.00, 2013, snp, http://www.vitruvius.com. $\mathrm{br} / \mathrm{revistas} / \mathrm{read} /$ arquitextos/13.153/4654.

${ }^{21}$ Presumivelmente, a segunda versão da revista com esse nome, editada em São Paulo, já que sua famosa homônima carioca encerrou as atividades em 1909. 
capitais, dentre os quais situa Sérgio Buarque de Holanda e Carlos Drummond de Andrade. Uma indicação do alinhamento do autor desse texto está em sua avaliação da origem do modernismo no Brasil, que ele associa com Graça Aranha, Oswald de Andrade e Ronald de Carvalho. "Foi, porém, Mário de Andrade quem levou sempre a verdadeira doutrina", escreve. ${ }^{22}$ A presença desse trecho é reveladora, porquanto sugere uma disputa pela liderança dentro do movimento e, pela primeira vez, situa Mário de Andrade como postulante ao cargo.

Ao contrário de seu conterrâneo Oswald de Andrade, o Correio da Manhã não concedeu muito espaço para Mário de Andrade nesses anos fundamentais da campanha modernista. Seu nome aparece citado pela primeira vez em 1923, em conexão com o lançamento dos "números 8 e 9 da revista Klaxon, órgão futurista, todo consagrado ao acadêmico sr. Graça Aranha". ${ }^{23}$ A partir de então, Mário passa a ser referido por suas ligações com outras publicações modernistas, como a revista Estética, de Prudente de Moraes Neto e Sérgio Buarque de Holanda; na coluna "Correio Musical", onde aparece, ora como autor de poemas musicados, ora em conexão com seus escritos no Diário Nacional; ou, muito em particular, como alvo de chacotas contra o modernismo. ${ }^{24}$ Mário foi resgatado de seu quase anonimato no grande diário carioca por ninguém menos do que José Oiticica - filólogo, poeta e professor, notório no Rio de Janeiro da época por sua participação na malograda tentativa de revolução anarquista de 18 de novembro de 1918 e prisão subsequente na ilha Rasa - o qual exercia a crítica literária nas páginas do Correio da Manhã. Em fins de junho de 1924 - poucas semanas antes de seu segundo encarceramento, na ilha das Flores, por ocasião da revolta de 5 de julho de 1924, em São Paulo - Oiticica publicou no jornal uma carta aberta a Graça Aranha, defendendo-o do ataque desferido na semana anterior por Oswald de Andrade. Nesse texto, ele toma partido contra os "versos futuristas dos srs. Mario de Andrade e Oswald de Andrade", assim como os "versos melindrosos, meia-tinta, dos srs. Guilherme de Almeida, Ronald de Carvalho ou

\footnotetext{
${ }_{22}$ Panorama do modernismo brasileiro. Correio da Manhã , Rio de Janeiro, 27/01/1929, suplemento, p. 3.

${ }^{25}$ Anch'io. Correio da Manhã, Rio de Janeiro, 12/05/1923, p. 4.

${ }^{24}$ Entre outros: Estética. Correio da Manhã, Rio de Janeiro, 08/09/1925, p. 2; VALERIO, Américo. Cirurgia e futurismo. Correio da Manhã, Rio de Janeiro, 10/07/1926, p. 3.
} 
Ribeiro Couto". ${ }^{25}$ Com a publicação dessa carta, teve início a contenda de Oiticica com os modernistas paulistas, pelos quais nutria conhecida aversão. ${ }^{26}$

A partir de 1925, José Oiticica resolve mirar sua ira literária em Mário de Andrade por meio de outra carta aberta, dessa vez endereçada a Prudente de Moraes Neto, a quem recrimina por lhe ter recomendado a leitura da Escrava que não era Isaura. ${ }^{27}$ A carta aberta transforma-se em resenha arrasadora do livro. $\mathrm{O}$ ataque se renova, uma semana depois, ao receber de Oswald de Andrade um exemplar de Pau Brasil, enviado por sua vez em resposta à carta aberta a Graça Aranha, publicada em junho. Oiticica dedica a maior parte desse novo texto a desmontar os argumentos expressos por Paulo Prado no prefácio do livro. Descarta as proposições de que a poesia Pau Brasil representaria uma descoberta da nacionalidade ou uma renovação da forma poética, arrolando exemplos anteriores de ambas as práticas, as quais ele acusa Prado de ignorar. Conclui que Oswald não faz "absolutamente nada de novo", mas apenas importa modismos do exterior e os alardeia paradoxalmente sob a bandeira do nacionalismo. As poesias dos modernistas - a quem Oiticica antes não negava o talento - são agora condenadas por serem fáceis, vulgares e desprovidas de emoção.

Entre a publicação do primeiro texto, às vésperas da revolta paulista de 1924, e esses últimos, ano e meio depois, a leve irritação literária do crítico se transformou em oposição empedernida e amarga. A conclusão do artigo é reveladora. Comentando o que ele apelida ironicamente de "grupo heroico de S. Paulo", Oiticica confessa não ter "nenhuma ilusão (...) sobre o movimento" e, na última linha, destacada do resto por ponto parágrafo, tacha suas produções de: "Agitações efêmeras e inócuas". ${ }^{28}$ Diante da cronologia dos fatos, é tentador ler os itálicos com que enfatiza as palavras "heroico" e "movimento", e ainda mais o emprego do termo "agitações", como referências veladas aos acontecimentos de julho de 1924 - durante os quais diversos modernistas se dispersaram e buscaram refúgio em fazendas. ${ }^{29}$ Embora não haja uma acusação explícita, seria compreensível o ressentimento do anarquista preso duas vezes contra o cafeicultor burguês posando de revolucionário.

\footnotetext{
${ }^{25}$ OITICICA, José. Espírito novo. Correio da Manhã, Rio de Janeiro, 28/06/1924, p. 4.

${ }^{26}$ PRADO, Antonio Arnoni. Elucubrações dramáticas do professor Oiticica. Estudos Avançados. São Paulo: USP, v. 14, n. 40, 2000, snp, http://www.scielo.br/scielo.php?script=sci_arttextE pid=S0103-40142000000300021\#14not.

${ }^{27}$ OITICICA, José. Poética modernista. Correio da Manhã, Rio de Janeiro, 19/09/25, p. 4

${ }^{28}$ OITICICA, José. Pau Brasil. Correio da Manhã, Rio de Janeiro, 26/09/1925, p. 4.

${ }^{29}$ AMARAL, Aracy A. Blaise Cendrars no Brasile os modernistas. São Paulo: Editora 34/Fapesp, 1997, p. 130.
} 
As investidas de José Oiticica contra Oswald e Mário de Andrade não ficaram sem resposta na cobertura equilibrada do Correio da Manhã. Os críticos José Clemente e Renato Vianna saltaram à defesa dos paulistas em textos publicados em outubro de 1925, o primeiro rebatendo as críticas de Oiticica e fazendo o elogio explícito de Paulo Prado, que ele descreve como "uma das inteligências mais curiosas e interessantes deste país de literatos integralmente peróbicos". ${ }^{30}$ Porém, voltando a tratar de Mário de Andrade no mês seguinte, José Clemente revela uma divisão em suas lealdades. Ao comentar insinuações maliciosas feitas contra Graça Aranha, o qual teria sido acusado por Mário de reivindicar "para si a glória de ter modernizado o espírito brasileiro", o crítico recusa-se a acreditar que o ex-acadêmico "desça a esmiuçar essas ninharias". “Demos ao sr. Graça Aranha o que é do sr. Graça Aranha. Façamos justiça ao muito que se lhe deve", escreve Clemente, retomando o elogio ao patrono percebido do modernismo. ${ }^{31}$

Essas contraposições de Graça Aranha, aclamado quase por unanimidade pelos colaboradores do Correio da Manhã, a Oswald de Andrade e a Mário de Andrade, indicam uma rixa pela liderança do movimento modernista. No caso de Oswald, que atacou Graça Aranha frontalmente nas páginas do jornal, a rivalidade é explícita; no caso de Mário, é mais sutil. Em raro elogio a Mário no Correio da Manhã dessa época, ele é descrito em 1927 como “a única manifestação de originalidade que se nota, presentemente, nas letras de São Paulo". ${ }^{32}$ É significativo que a afirmação conste da "Página paulista do Correio da Manhã organizada pela nossa sucursal" e assinada por um colaborador estranho às colunas literárias habituais do jornal. No ano seguinte, em resenha de livros de poesias, o veterano escritor e crítico Nestor Victor dá outra pista para compreender os meandros das maquinações politiqueiras, ao afirmar sobre Jorge de Lima: "Mas, por certo que não o teríamos se a influência de Mário de Andrade não se houvesse propagado tanto e não fosse levada ao Norte, sobretudo por intermédio de Manuel Bandeira". A importância das relações regionais reaparece no mesmo artigo quando Nestor Victor afirma que a ingerência de São Paulo sobre o Paraná faz com que os escritores paranaenses

\footnotetext{
${ }^{30}$ CLEMENTE, José. Poesia Pau Brasil. Correio da Manhã, Rio de Janeiro, 01/10/1925, p. 4; VIANNA, Renato. Coisas da China. Correio da Manhã, Rio de Janeiro, 21/10/1925, p. 2. Vale a pena atentar para o jogo de palavras entre peroba, oiticica e pau-brasil - todas, espécies de árvore - e a constituição de um discurso literário que empregava referências à natureza para atribuir ou retirar legitimidade.

${ }^{31}$ CLEMENTE, José. Kultur e anti-intelectualismo. Correio da Manhã, Rio de Janeiro, 12/11/1925, p. 4.

32 GILBERT, João. Política e literatura. Correio da Manhã, Rio de Janeiro, 01/04/1927, p. 4.
} 
se alinhem "com o paulista Mario de Andrade", até mesmo em detrimento dos "paranaenses vanguardistas" que se encontram no Rio de Janeiro. ${ }^{33}$ Dada a preponderância, durante os anos 1920, dessa visão de Mário de Andrade como militante da causa paulista, deve ter causado surpresa aos leitores de 1929 encontrarem seu nome elevado à condição de guardião da "verdadeira doutrina" modernista, em pleno suplemento de domingo do Correio da Manhã.

A arte moderna voltou a agitar o meio artístico do Rio de Janeiro no primeiro semestre de 1930, com a inauguração de exposição de pintura moderna no Palace Hotel, então um dos principais endereços da capital para mostras de arte (além da Escola Nacional de Belas Artes, o Liceu de Artes e Ofícios, a Sociedade Brasileira de Belas Artes e a Galeria Jorge). Organizada pelo pintor pernambucano Vicente do Rego Monteiro e pelo poeta francês Géo-Charles, ligado à revista Montparnasse, essa exposição trouxe para o Brasil obras de Léger, Lhote, Lurçat, Masson, Matisse, entre outros ligados à chamada Escola de Paris, aportando primeiramente em Recife e seguindo depois para o Rio de Janeiro e São Paulo. A primeira notícia no Correio da Manhã, em abril de 1930, apresenta Rego Monteiro como um "pintor moderno, com uma individualidade segura e definida", laureado e admirado em Paris, mas não faz nenhuma menção ao seu envolvimento com a Semana de Arte Moderna, aspecto que o jornal parece ignorar. ${ }^{34}$ Em maio, a exposição volta novamente às páginas do Correio da Manhã, desta vez por meio de uma crítica assinada por Lelio Landucci - então envolvido no projeto do Cristo Redentor - na qual o escultor italiano lamenta que ela não tivesse atraído tanta atenção quanto merecia. Landucci defende a mostra de críticas hipotéticas, principalmente da acusação de que "chegou atrasada esta exposição", e lamenta a "hostilidade combativa da gente que interpreta o conjunto dos esforços apresentados como um desaforo". ${ }^{35}$ A primeira objeção de Landucci lembra a acusação de "atraso" feita por Oswald de Andrade, seis anos antes, contra Graça Aranha, e a segunda confirma a percepção de que, apesar das campanhas a favor, ainda existia forte resistência à arte moderna. Os promotores do movimento se encontravam imprensados entre duas posições antagônicas: por um lado, a velha crítica conservadora que via arte moderna como um disparate e, por

\footnotetext{
33 VICTOR, Nestor. Livros nossos e outros. Correio da Manhã, Rio de Janeiro, 11/05/1928, p. 2.

${ }^{34}$ Uma exposição de pintura moderna nesta capital. Correio da Manhã, Rio de Janeiro, 06/04/1930, p. 2.

${ }^{35}$ LANDUCCI, Lelio. Variações sobre a exposição de pintura moderna no Palace. Correio da Manhã, Rio de Janeiro, 29/05/1930, p. 2.
} 
outro, uma nova crítica moderníssima que cobrava maior atualidade - até mesmo de uma exposição trazida de Paris.

O período entre as eleições de março de 1930 e a instalação do Governo Provisório em 3 de novembro de 1930 - passando pelo assassinato de João Pessoa, em julho, e o golpe desencadeado em outubro - foi de grande instabilidade, marcado por um emaranhado de conflitos e interesses. Apreende-se das páginas do Correio da Manhã, nesse momento, certa desagregação dos grupos modernistas, por conta das poucas notícias veiculadas sobre arte moderna entre os meses de julho e dezembro. Com o sucesso da Revolução de 1930, a relação dos modernistas com as instituições artísticas consolidadas entrou em fase aguda de conflito. A passagem controvertida de Lúcio Costa pela direção da Escola Nacional de Belas Artes, entre fins de 1930 e setembro de 1931, constitui o confronto mais notório entre esses campos de força. ${ }^{36}$ Não há dúvida de que sua breve gestão aprofundou divisões existentes e foi percebida por ambos os lados como uma declaração de guerra - os modernistas tentando tomar de assalto a ENBA e galvanizando a reação dos tradicionalistas que, até então, não haviam agido em bloco. O saldo do confronto foi inconclusivo. Embora os artistas modernos tenham conseguido dominar o Salão "revolucionário" de 1931, Lúcio Costa acabou exonerado da direção. A ENBA retomou uma orientação ainda mais conservadora sob seu novo diretor, Archimedes Memória; e a arte moderna se viu destituída de base institucional na esfera federal, pelo menos até a nomeação de Gustavo Capanema como ministro, na pasta de Educação e Saúde, o que só ocorreria em julho de 1934.

\section{A vitória do modernismo, 1931-1935}

O falecimento de Graça Aranha, em janeiro de 1931, foi o mote para que o assunto do modernismo voltasse com força, após um período de quietude relativa. O obituário publicado no Correio da Manhã afirma que o escritor "organizou o movimento de arte moderna, congregando em torno de si todos os escritores novos do nosso país" e que "efetivou a "Semana de Arte Moderna', em 1922". ${ }^{37}$ Qualquer exagero poderia ser atribuído à emoção que aflora

\footnotetext{
${ }^{36}$ BRESSAN PINHEIRO, Maria Lúcia. Lúcio Costa e a Escola Nacional de Belas Artes. In: $6^{\circ}$ SEMINÁRIO DOCOMOMO-BRASIL. Anais. Niterói: 2005, snp, http://www.docomomo.org.br/ seminario\%206\%20pdfs/Maria\%20Lucia\%20Bressan\%20Pinheiro.pdf. Ver também GOUVÊA VIEIRA, op. cit., p. 23-28; LISSOVSKY \& MORAES DE SÁ, op. cit., p. xiii-xiv.

${ }^{37}$ Graça Aranha. Correio da Manhã, Rio de Janeiro, 27/01/1931, p. 3.
} 
nos necrológios; porém, na mesma página do jornal daquele dia, outro artigo confirma que um projeto de "irradiação do movimento modernista no Brasil", constituído em torno de Graça Aranha, já estava em gestação havia alguns meses. A matéria anuncia os nomes dos vencedores dos prêmios distribuídos pela Fundação Graça Aranha, recém-criada, para o ano de 1930: Rachel de Queiroz, na categoria romance; Murilo Mendes, na poesia; e Cícero Dias, na pintura. ${ }^{38}$ Vasculhando nas notas do jornal, descobre-se que, desde setembro, um grupo sob a coordenação de Eugênia Álvaro Moreyra esposa do escritor e jornalista Álvaro Moreyra, então diretor da revista Para Todos e um dos remanescentes do grupo dos "doze apóstolos do modernismo", assim identificado por Mário de Andrade em 1922 - vinha agitando a programação em torno de um Departamento de Arte Moderna inaugurado na Casa do Estudante do Brasil..$^{39}$ Quando as atividades da Fundação Graça Aranha voltam a ocupar as páginas do Correio da Manhã dois anos e meio depois de sua criação, o nome dela continua associado à empreitada. ${ }^{40}$

Em 24 de junho de 1933, uma "tarde modernista" - com música de Satie, Poulenc, Stravinsky, Falla e Villa-Lobos, e récita de poesias modernistas brasileiras declamadas por Eugênia Álvaro Moreyra - abriu a Exposição de Arte Moderna promovida pela Fundação Graça Aranha e realizada no ateliê Nicolas, a qual foi frequentada, segundo o Correio da Manhã, não somente por muitos artistas, como também por "figuras de destaque no nosso mundo social, literário, diplomático e jornalístico". ${ }^{41}$ Entre os artistas incluídos na exposição estavam: Victor Brecheret, Tarsila do Amaral, Ismael Nery, Di Cavalcanti, Cícero Dias, Celso Antônio, Cecília Meirelles, Carlos Prado, Cândido Portinari, Bella Paes Leme, Antônio Gomide, Alfredo Herculano, Alberto da Veiga Guignard - uma mistura representativa e diversificada de nomes, contando com alguns dos mais próximos ao grupo semanista de 1922, mas também nomes novos do Rio de Janeiro. Na mesma tarde modernista, houve discurso de Renato de Almeida - um dos fundadores da Semana e próximo a Graça Aranha - pronunciado na condição de presidente de uma sociedade

\footnotetext{
${ }^{38}$ Fundação Graça Aranha. Correio da Manhã, Rio de Janeiro, 27/01/1931, p. 3.

${ }^{39}$ Mário de Andrade apud FABRIS, op. cit., p. 139. Eugênia Álvaro Moreyra parece ter exercido um papel de signo, em carne e osso, do modernismo vigente, conforme atesta seu retrato pintado por Dimitri Ismailovitch e exposto no Salão de 1931; ver GOUVÊA VIEIRA, op. cit., p. 116 \& fig. 15.

${ }^{40}$ Correio da Manhã, Rio de Janeiro, 10/09/1930, p. 6; A quinzena da Casa do Estudante e a tarde de ontem. Correio da Manhã, Rio de Janeiro, 11/09/1930, p. 5.

${ }^{41}$ A exposição de arte moderna e a tarde modernista da Fundação Graça Aranha. Correio da Manhã, Rio de Janeiro, 25/06/1933, p. 3.
} 
de arte moderna de São Paulo, infelizmente não identificada pelo texto do jornal. A fala de Renato de Almeida é laudatória, enfatizando a "vitória do modernismo" e passando por cima das divisões entre correntes - "Pau Brasil, grupo da anta, verde e amarelo, antropofagia - outras sem nome" - que ele situa como numerosas manifestações de uma única tendência. "O modernismo não mais se discute," segundo Renato de Almeida, que se coloca de modo conciliador. Vale citar por extenso um trecho desse discurso:

\begin{abstract}
O modernismo no Brasil, passando o período de choque, que começou na famosa Semana de Arte Moderna de São Paulo, em 1922, prolongando-se por vários anos afora, tendo como principais marcos a conferência de Graça Aranha, na Academia, em 1924, e a visita a esta capital de F. T. Marinetti, já entrou num período firme de construção. Hoje não provoca nem produz mais escândalo. A sensibilidade e a inteligência já se adaptaram às suas expressões e o modernismo não está apenas nesta pintura, nesta música, nesta arquitetura, nesta escultura, nesta poesia que aqui se apresenta. Está em toda parte; nos edifícios de cimento armado, nas casas modernas, que se espalham pela cidade, na arte decorativa, na moda feminina, na civilização veloz da máquina, e, mesmo nos centros mais reacionários - na Escola de Belas Artes, que já incluiu os modernistas no Salão de 1931, na Academia de Letras, que engoliu um dos nossos mais vibrantes companheiros, modernista de primeira hora, Guilherme de Almeida! ${ }^{42}$
\end{abstract}

Renato de Almeida encerra esse discurso revelador, que confirma a trajetória narrada nas páginas do Correio da Manhã, com o elogio da Fundação Graça Aranha por agregar as diversas forças do movimento dentro de uma compreensão alargada do espírito moderno.

Mesmo descontando o tom diplomático exigido pela ocasião, o momento parece mesmo ter sido de consolidação de forças, ou pelo menos de tentativas nesse sentido. A Sociedade Pró-Arte Moderna (Spam) foi fundada no final de 1932, reunindo os principais atores do movimento modernista em São Paulo em torno de Lasar Segall, e contando com a participação de Paulo Prado, Tarsila do Amaral, Anita Malfatti, entre muitos outros. A primeira exposição da Spam foi noticiada, elogiosamente, pelo Correio da Manhã em maio de 1933, e o jornal chegou a anunciar que ela viria, em seguida, para o Rio de Janeiro, sob os auspícios da Sociedade Pró-Arte, para ser instalada na "Academia de Belas Artes" (conforme grafou o artigo, em saboroso ato falho). ${ }^{43}$ Por mais improvável que possa parecer essa nova invasão da

\footnotetext{
${ }^{42}$ Ibid.

${ }^{43}$ A exposição de arte moderna, em S. Paulo. Correio da Manhã, Rio de Janeiro, 07/05/1933, p. 10.
} 
Escola Nacional de Belas Artes por uma exposição modernista, o marchand Theodor Heuberger - que dirigia a referida Sociedade Pró-Arte, de intercâmbio cultural entre Brasil e Alemanha, fundada em 1930 - chegou, de fato, a organizar diversas mostras de tendência moderna ali nos anos 1928 a 1933, assim como no Liceu de Artes e Ofícios e na galeria que mantinha no edifício da Associação dos Empregados do Comércio. ${ }^{44}$ Identifica-se um trânsito interessante entre os círculos modernistas de Rio de Janeiro e São Paulo no final dos anos 1920 e início dos anos 1930. Lasar Segall e Tarsila do Amaral realizaram exposições no Palace Hotel, respectivamente em julho de 1928 e julho de 1929, bem recebidas pela imprensa carioca - em especial, pelos órgãos que faziam campanha a favor do modernismo, como o diário $O$ Jornal e a revista Para Todos. ${ }^{45}$ No caso de Tarsila, trata-se de sua primeira exposição individual no Brasil, sendo notável a opção por fazê-la no Rio, em vez de São Paulo. ${ }^{46}$ Não por acaso, a pintora mantinha relações estreitas de amizade com Álvaro Moreyra e sua esposa Eugênia. ${ }^{47}$ Eles integravam uma rede de sociabilidade em que recorrem ainda os nomes de Segall e Luís Martins (companheiro de Tarsila entre 1934 e 1952).

Um reflexo desse intercâmbio entre grupos e correntes é a publicação no Correio da Manhã, em maio de 1934, do comunicado de inauguração do Clube de Cultura Moderna, estabelecido com o intuito de coordenar a arte moderna e fiscalizar a produção artística, posicionando-a contrária à "arte ensinada em nossos estabelecimentos oficiais". ${ }^{48}$ Entre os membros do conselho diretor da entidade são listados pelo jornal: Alberto da Veiga Guignard, Annibal M. Machado, Cândido Portinari, Carlos Leão, Celso Antônio, Cícero Dias, Di Cavalcanti, J. Queiroz Lima, Lúcio Costa, Manuel Bandeira, Pedro Correia de Araújo - vários dos quais estiveram presentes na mostra da Fundação Graça Aranha, no ano anterior. A exposição subsequente da entidade

\footnotetext{
${ }^{44}$ GOUVÊA VIEIRA, op. cit., p. 19-24.

${ }^{45}$ Ver, entre outros: Exposições. Correio da Manhã, Rio de Janeiro, 07/07/1928, p. 5; Lasar Segall. $O$ Jornal, Rio de Janeiro, 11/07/1928, Belas Artes, p. 5, 7; Para Todos, Rio de Janeiro, 27/07/1929, p. 14; BEZERRA DE FREITAS. Antropofagia. Para Todos, Rio de Janeiro, 27/07/1929, p. 17; GUSMÃO, Clóvis de. Na exposição de Tarsila. Para Todos, Rio de Janeiro, 03/08/1929, p. 21.

${ }^{46}$ Cf. GOUVÊA VIEIRA, op. cit., p. 21.

${ }^{47}$ MARTINS, Ana Luisa. Aí vai meu coração: As cartas de Tarsila do Amaral e Anna Maria Martins para Luís Martins. São Paulo: Global, 2010, p. 29-30.

${ }^{48}$ Clube de arte moderna. Correio da Manhã, Rio de Janeiro, 24/05/1935, p. 3. Nessa ocasião, o jornal grafa o nome como Clube de Arte Moderna. Não confundir com o Clube dos Artistas Modernos, o famoso CAM de São Paulo, fundado em 1932, sob a liderança de Flávio de Carvalho, Di Cavalcanti e Antônio Gomide.
} 
ocorreu em setembro de 1935, contando com obras de Cândido Portinari, Di Cavalcanti, Lasar Segall, Noêmia Mourão, Oswaldo Goeldi, Paulo Werneck, Santa Rosa, entre outros, e ainda palestras de Álvaro Moreyra, Annibal Machado e Santa Rosa. ${ }^{49}$ Essa mostra ficou conhecida como Exposição de Arte Social, alcunha que revela seu alinhamento com o ideário da Aliança Nacional Libertadora, adesão formalizada pelo Clube em julho de $1935 .^{50} \mathrm{~A}$ admiração aberta que alguns de seus integrantes manifestavam por Luís Carlos Prestes ficava ainda mais explícita na revista do Clube de Cultura Moderna, Movimento, que chegou a publicar apenas quatro números, fruto dos esforços de Santa Rosa e Paulo Werneck. ${ }^{51}$

Essa coesão entre nomes de Rio e São Paulo em torno de um projeto de engajamento social da arte representa o florescimento da comunhão entre grupos modernistas. Porém, apesar de indícios de cooperação e coalizão entre Sociedade Pró-Arte, Spam, Fundação Graça Aranha e Clube de Cultura Moderna, entre os anos de 1932 e 1935, só o leitor mais desavisado do Correio da Manhã poderia acreditar que todas as dissensões e divergências no meio modernista houvessem sido superadas. O momento era de sérios conflitos políticos, concretizados de modo dramático pelos acontecimentos em torno da Revolução Constitucionalista. Seria impossível, na sequência dos combates ocorridos entre forças federais e constitucionalistas entre julho e outubro de 1932, que a chamada "guerra paulista" não estivesse presente nas mentes das pessoas que agitavam essas organizações. Ao contrário, é provável que o fato tenha pesado de modo decisivo, pelo menos na cronologia de fundação das agremiações paulistas Spam e CAM, inauguradas ambas pouco tempo depois do fim das hostilidades. Ressente-se da falta de estudos mais aprofundados sobre as relações entre os diversos grupos modernistas e a Revolução de 1932. Tirante Guilherme de Almeida, ativo combatente do lado paulista, e Di Cavalcanti, que sofreu prisão em São Paulo como getulista, há uma escassez surpreendente de informações sobre o envolvimento dos principais vultos ligados ao modernismo. Com a cisão da coalizão de forças que havia conduzido à vitória da Revolução de 1930 e o legado tenentista posto

\footnotetext{
${ }^{49}$ Exposições. Correio da Manhã, Rio de Janeiro, 20/09/1935, p. 7; Mostra de arte do clube de cultura moderna. Correio da Manhã, Rio de Janeiro, 24/09/1935, p. 4.

${ }^{50}$ OLIVEIRA, Ângela Meirelles de. Intelectuais antifascistas no cone sul: Experiências associativas no cruzamento entre a cultura e a política (1933-1939). Projeto História São Paulo. São Paulo: PUC-SP, n. 47, 2013, revistas.pucsp.br/index.php/revph/article/download/17134/14201.

51 AMARAL, Aracy. Arte para quê?: A preocupação social na arte brasileira (1930-1970). São Paulo: Nobel, 1984, p. 49-55.
} 
em xeque, os anos entre 1932 e 1935 testemunharam uma polarização entre comunistas e integralistas que ecoava os acontecimentos internacionais, como a ascensão de grupos de extrema-direita na Itália, Alemanha e França.

Nesse contexto carregado de embates ideológicos, uma das ocorrências mais surpreendentes veiculadas pelo Correio da Manhã, em sua cobertura da arte moderna, está relacionada ao regresso do pintor Cândido Portinari após uma temporada de dois anos na Europa. Procurado pelo jornal para uma entrevista, o jovem pintor se lança em elogio rasgado ao fascismo:

Na Itália - conta -, o fascismo é um animador formidável de energias moças. Mussolini, o gigante que todos nós conhecemos, que fez a Itália do progresso e está fazendo o povo do trabalho, é o dínamo propulsor da pintura nova. Em todas as exposições de arte moderna, a voz do condottiere se faz ouvir na inauguração; e o seu discurso é um hino de ânimo e de fé. Prampoline e Tosti surgiram com o fascismo, inflamados pelo verbo do primeiro ministro. ${ }^{52}$

Para uma posteridade acostumada a pensar em Portinari como militante comunista, e até candidato a cargos eletivos pelo PCB após 1945, tais afirmações são nada menos do que bombásticas; mas elas refletem o clima de confusão e radicalização que cercam as discussões sobre arte moderna no período. Durante toda a década de 1930, as páginas do Correio da Manhã seriam palco para disputas de natureza ideológica, que se tornariam mais acirradas e azedas após a revolta militar de novembro de 1935 - a chamada Intentona Comunista - e durante a escalada de acontecimentos que conduziu ao golpe do Estado Novo, dois anos depois.

Desde a década de 1920, como se viu, já se explicitara nas páginas do Correio da Manhã uma ponte entre arte moderna e a Revolução Russa. No entanto, essa faceta se limitou à constatação de um vínculo histórico e, mesmo assim, dentro de um texto estrangeiro. Àquela altura, ainda não pairava nenhuma suspeita de ligações diretas entre o movimento modernista no Brasil e o comunismo. A se julgar pelos posicionamentos de figuras como José Oiticica - anarquista e opositor do modernismo - ou Cândido Portinari - pintor moderno e admirador do fascismo - inexistia no início da década de 1930 um alinhamento forçoso e necessário entre uma posição política de esquerda e pertencimento aos quadros modernistas. Ao contrário, algumas correntes modernistas - notadamente, os grupos da Anta e Verde-Amarelo

\footnotetext{
${ }^{52}$ Um pintor que volta da Europa. Correio da Manhã, Rio de Janeiro, 31/01/1931, p. 3.
} 
- pendiam, por essa época, na direção do integralismo nascente, o qual se consolidaria como Ação Integralista Brasileira em outubro de 1932. Nunca é demais lembrar que Plínio Salgado, antes de ser integralista, foi considerado um escritor modernista..$^{53}$

Os primeiros sinais de mudança dessa percepção começam a transparecer das páginas do Correio da Manhã a partir de fins de 1932, logo após o término da Revolução Constitucionalista. Nessa época, alguns articulistas forjam elos entre a arte moderna e inquietação social ou, até mesmo, revolução. No suplemento de domingo, o escritor gaúcho Fernando Callage, então radicado em São Paulo, chega a afirmar a existência de uma "nova mentalidade brasileira" nos seguintes termos:

Se politicamente já tínhamos avançado alguma coisa em 1822, só em 1922, um século depois, com a chamada revolução da arte moderna no municipal de S. Paulo, e posteriormente com o "verde-amarelismo" e a revolução da Anta, criávamos de fato, uma independência espiritual. ${ }^{54}$

Citando Plínio Salgado e Tristão de Athayde, o autor coloca o modernismo como uma "revolução", apropriando-se tão deliberadamente da expressão que a emprega duas vezes na frase. Outro articulista gaúcho, o historiador Paulino Jacques, escrevendo no mesmo suplemento e na mesma época, escolheu o título "Revolução e arte" para falar favoravelmente da relação entre arte e anarquia. ${ }^{55}$ Mais uma vez, o Correio da Manhã toma o cuidado de equilibrar sua cobertura, contrapondo opiniões divergentes. Essa pequena disputa pela posse do termo "revolução", nas páginas do suplemento dominical, espelhava questões maiores que pairavam na sociedade brasileira no momento de consternação que cercou a derrota dos constitucionalistas de 1932 e a fundação da Ação Integralista. Não pode ser tido como mero acaso que os dois últimos meses do ano tenham testemunhado também a inauguração da Spam e do CAM. Após a derrota, São Paulo precisava se reorganizar, e os reflexos disso sobre o modernismo paulista são assunto digno de maior investigação. De todo modo, não resta dúvida de que a unidade hesitante

\footnotetext{
53 PRADO, Antonio Arnoni. 1922 - Itinerário de uma falsa vanguarda: Os dissidentes, a Semana e o Integralismo. São Paulo: Brasiliense, 1983, p. 93-100.

${ }^{54}$ CALLAGE, Fernando. A nova mentalidade brasileira. Correio da Manhã, Rio de Janeiro, 18/12/1932, suplemento, p. 2.

${ }^{55}$ JACQUES, Paulino. Marinetti e a inquietação artística. Correio da Manhã, Rio de Janeiro, 04/09/1932, suplemento, p. 2; JACQUES, Paulino. Revolução e arte. Correio da Manhã, Rio de Janeiro, 16/10/1932, suplemento, p. 2.
} 
dos anos 1931 a 1932 se fragmentava, dando lugar a uma nova polarização entre direita e esquerda.

\section{Cultura moderna ecosmopolitismobolchevizante, 1935-1937}

Entre 1932 e 1933, trava-se outra batalha de palavras, mais sutil, no suplemento dominical do Correio da Manhã em torno da aplicação do termo "moderno" à arte. O jornalista e crítico Tapajós Gomes, de orientação tradicionalista, não hesitou em atribuir atualidade a artistas tão distantes do movimento modernista quanto Oswaldo Teixeira e Henrique Cavalleiro, sendo que este último ele descreve como uma das grandes individualidades "entre os artistas da moderna geração brasileira". ${ }^{56}$ A delicada inversão do adjetivo não esconde o contraste entre sua apreensão do moderno e aquela do arquiteto J. Cordeiro de Azeredo, já citado, que escrevia também no suplemento dominical ao longo do mesmo período. Ainda mais reveladora é a atuação do pintor modernista Pedro Correia de Araújo, o qual escreveu regularmente sobre arte no Correio da Manhã entre 1933 e 1937, época em que também integrava o conselho diretor do Clube de Cultura Moderna e lecionava desenho no Instituto de Artes da Universidade do Distrito Federal. Entre os artigos de Correia de Araújo, há crônicas imaginárias em que três personagens discutem os rumos do meio artístico: de um lado, o modernista e comunista Anargono e, do outro, o passadista e acadêmico Fotofil - cujos partidos são apelidados, respectivamente, de "cubangolistas" versus "coveiros". Arbitrando os debates, e quase sempre demonstrando que nem um nem outro detêm toda a razão, paira o personagem Theodoro, que prega a boa vontade e a união. ${ }^{57}$

A boa vontade, se é que existiu um dia, esgotou-se em 1935, com o levante comunista nos quartéis de Natal, Recife e Rio de Janeiro, entre 23 e 27 de novembro. Poucos dias depois, estampa a primeira coluna da página 4, local comumente dedicado à crítica literária, um artigo de Carlos Maul, jornalista e escritor reacionário (no sentido mais estrito do termo), intitu-

\footnotetext{
${ }_{56}$ TAPAJÓS GOMES. Henrique Cavalleiro. Correio da Manhã, Rio de Janeiro, 11/09/1932, suplemento, p. 2; Idem. Oswaldo Teixeira - o artista gigante. Correio da Manhã, Rio de Janeiro, 16/10/1932, suplemento, p. 1; Ibidem. O estilo decorativo brasileiro. Correio da Manhã, Rio de Janeiro, 06/11/1932, suplemento, p. 1.

${ }^{57}$ ARAÚJO, Pedro Correia de. Theodoro. Correio da Manhã, Rio de Janeiro, 05/11/1933, suplemento, p. 2; Idem. Contribuição de Theodoro às belas artes. Correio da Manhãa, Rio de Janeiro, 09/05/1937, suplemento, p. 4.
} 
lado "Palavras aos intelectuais brasileiros". ${ }^{58}$ No clima tenso de repressão da "grave rebelião militar", Maul lembra as "graves responsabilidades" dos intelectuais e aponta o dedo para o "cosmopolitismo bolchevizante" que, segundo ele, infesta as escolas, as universidades, as editoras e, em especial, a arte moderna. Ele acusa o Clube de Cultura Moderna de abrigar "os maiorais do comunismo indígena". Maul fulmina: "A 'cultura moderna' aí propagada vem da Rússia, via Paris e Barcelona, em traduções baratas e abrange tudo o que se tem publicado com origem do marxismo". Aos escritores e editores modernistas, ele imputa a difusão de "sementes da corrupção"; aos pintores e desenhistas, o "primitivismo infantil" e "o bolchevismo dos assuntos". O próprio Departamento de Difusão Cultural do governo estaria infiltrado por essas orientações esquerdistas, avisa Maul, "e o pior é que há desses suja-paredes guindados ao magistério em rendosos postos de professores de desenho, mentores do gosto da juventude!". Seu colega de jornal, Correia de Araújo, não podia estar longe da mente do autor.

O alvo do ataque é o Instituto de Artes da Universidade do Distrito Federal onde lecionavam, entre outros: Andrade Muricy, Albuquerque da Costa, Arnaldo Estrella, Carlos Leão, Georgina de Albuquerque, Nestor de Figueiredo, Oscar Lorenzo Fernandes, Portinari, Villa-Lobos, sob a direção de Celso Kelly. O projeto educacional da UDF, criada em abril de 1935 e inaugurada em julho, era de autoria de Anísio Teixeira, secretário de educação do prefeito Pedro Ernesto. Na decorrência imediata do movimento de novembro, o prefeito se viu obrigado a exonerar Anísio Teixeira, assim como o reitor da UDF, Afrânio Peixoto, e vários professores, incluindo Celso Kelly, todos por suspeita de envolvimento com os comunistas. Os professores do Instituto de Artes, listados acima, anunciaram sua demissão coletiva em solidariedade ao diretor exonerado, mas este se recusou a aceitá-la em carta reproduzida no Correio da Manhã em 6 de dezembro de 1935. ${ }^{59}$ No desenlace dramático do episódio, o próprio prefeito seria preso, em abril de 1936, em virtude de "indícios veementes da culpabilidade do dr. Pedro Ernesto na preparação dos movimentos subversivos que abalaram o país", conforme a

\footnotetext{
${ }^{58}$ MAUL, Carlos. Palavras aos intelectuais brasileiros. Correio da Manhã, Rio de Janeiro, 05/12/1935, p. 4. Na outra extremidade da página, a manchete "Camisas verdes", em negrito e com corpo avantajado, encabeça uma matéria criticando a sugestão, votada pela Câmara dos Deputados, de que o presidente decrete o fechamento da Ação Integralista Brasileira.

${ }^{59}$ Os professores do Instituto de Artes solidários com o senhor Celso Kelly. Correio da Manhã, Rio de Janeiro, 06/12/1935, p. 3.
} 
declaração da polícia publicada no jornal. ${ }^{60} \mathrm{O}$ Instituto de Artes se manteve em atividade, sob a direção de Cornélio Penna, por um tempo. Em seguida ao golpe de novembro de 1937, o Estado Novo deu início à extinção da UDF, que acabou sendo incorporada à Universidade do Brasil, em 1938. ${ }^{61}$

Teve continuidade a investida furiosa de Carlos Maul contra "a 'arte moderna' tão do agrado dos comunistas como instrumento de corrupção". ${ }^{2}$ Mesmo decorridos seis meses desde a sublevação militar, a violência de seus ataques não arrefeceu nem um pouco:

O futurismo, ou mais precisamente o "modernismo" que é o rótulo bolchevista da arte grosseira e aleijada da atualidade, chegou também à nossa terra e continua a produzir seus resultados maléficos, mercê da despreocupação dos verdadeiros valores que não se defendem, e muito menos defendem as conquistas autênticas da nossa cultura. ${ }^{63}$

É reveladora a distinção preciosa introduzida entre "futurismo" e "modernismo", livrando o futurista Marinetti - a essa altura, firmemente alinhado com Mussolini - de inclusão sob o "rótulo bolchevista". ${ }^{64}$ As circunstâncias políticas forneceram ao autor o pretexto para um ajuste de contas que alcançava até muito antes de 1935. No mesmo artigo, Maul acusa a "direção comunista" implantada na Escola Nacional de Belas Artes após a Revolução de 1930 de ter alçado os "suja-paredes" a um patamar de igualdade com os outros artistas da casa, introduzindo suas obras no Salão que ele apelida de "bacanal de 1931". A referência é tardia, mas não gratuita. A fúria continuada de Maul tinha outro alvo. No momento em que escrevia essas linhas, era recente o desenlace do concurso para a construção do edifício do Ministério da Educação e Saúde, em que o vencedor Archimedes Memória foi preterido por Capanema a favor de Lúcio Costa. Em carta de protesto enviada a Getúlio Vargas, Memória chegou a denunciar o Clube de Cultura Moderna como "célula comunista" e a lançar desconfiança sobre Lúcio Costa por ser sócio de

\footnotetext{
${ }^{60}$ Detido o prefeito do Distrito Federal. Correio da Manhã, Rio de Janeiro, 04/04/1936, p. 1.

${ }^{61}$ SCHWARTZMAN, BOMENY \& COSTA, op. cit., p. 221-246; ver também SANTOS DE SOUZA, Lidiane Diniz Fernandes. Costa Rego e o curso pioneiro de jornalismo da Universidade do Distrito Federal. Dissertação de mestrado inédita, Programa de Pós-Graduação em Comunicação Social, Universidade Metodista de São Paulo, 2010, p. 65-76, http://ibict.metodista.br/tedeSimplificado/ tde_busca/arquivo.php?codArquivo $=2331$.

${ }^{62}$ MAUL, Carlos. O rei está nu. Correio da Manhã, Rio de Janeiro, 14/05/1936, p. 4.

${ }^{63}$ MAUL, Carlos. O espírito subversivo do modernismo. Correio da Manhã, Rio de Janeiro, 25/06/1936, p. 4

${ }^{64}$ Sobre o emprego estratégico dos termos "futurismo" e "modernismo", ver FABRIS, op. cit., esp. caps. 5 e 6.
} 
Gregori Warchavchik, que ele chama de "judeu russo de atitudes suspeitas", e ainda acusou Carlos Drummond de Andrade de "patrono e intransigente defensor" desses elementos em sua condição de chefe de gabinete do ministro. ${ }^{65} \mathrm{O}$ acirramento de ânimos era grande. Em março de 1936, Drummond colocou seu cargo à disposição, por se recusar a comparecer à palestra "A educação e o comunismo", proferida por Alceu de Amoroso Lima, a convite de Capanema. Mesmo negando ter "posição à esquerda", Drummond sentia que sua presença seria uma traição aos companheiros. ${ }^{66}$ Nesse clima, a decisão de Capanema sobre o concurso do edifício pode ser vista como "prêmio de consolação" - não somente para compensar o grupo de Lúcio Costa e Le Corbusier pelo engavetamento de seu projeto para a Cidade Universitária, conforme sugerem Schwartzman, Bomeny e Costa - como também pelo revés de 1931 quando Costa foi substituído na direção da ENBA pelo integralista Archimedes Memória, e ainda como afago pessoal a Drummond. ${ }^{67}$

Por sua atuação estratégica no Correio da Manhã nesse momento, a figura de Carlos Maul merece maior escrutínio. Poeta e literato, Maul se candidatou a uma vaga na Academia Brasileira de Letras, em março de 1930, mas se viu derrotado por Guilherme de Almeida. É possível que tenha originado daí seu ódio mortal aos modernistas; porém, seria injusto negar a profundidade de sua aversão ideológica à arte moderna. Durante a primeira metade da década de 1930, o escritor engajou-se em diversas causas cívicas - notadamente, a campanha vitoriosa contra o acordo ortográfico luso-brasileiro de 1931, bem como outra, de invenção sua, para criar a figura de "Vovô Índio" em substituição ao Papai Noel. ${ }^{68}$ Da sua defesa dessas causas, entre outras, depreende-se um nacionalismo e um nativismo militantes, alinhados vagamente com o "verde-amarelismo" de orientação integralista. Contudo, Maul não se posicionava abertamente como partidário da Ação Integralista Brasileira; antes, foi membro fundador do Partido Evolucionista Fluminense, pelo qual se lançou candidato a deputado estadual no Estado do Rio de Janeiro, em 1934. Muito ativo como jornalista, ele era colaborador regular do jornal O País e da rádio Mayrink Veiga, e contribuía ainda com artigos e contos para vários órgãos, incluindo O Malho, Nação Brasileira, Carioca e a Revista da Light, assim como o próprio Correio da Manhã, para o qual costumava escrever

\footnotetext{
${ }^{65}$ Apud LISSOVSKY E MORAES DE SÁ, op. cit., p. 26.

${ }^{66}$ SCHWARTZMAN, BOMENY \& COSTA, op. cit., p. 101-102.

${ }^{67}$ Ibid., p. 119.

${ }^{68}$ MAUL, Carlos. Vovô índio. Correio da Manhã, Rio de Janeiro, 31/12/1932, p. 7.
} 
resenhas literárias. Maul cultivava ligações pessoais tanto com o diretor do jornal, M. Paulo Filho, quanto com seu redator-chefe, Costa Rego, no âmbito da Associação Brasileira de Imprensa (ABI).

Apesar do clima pouco favorável na cidade e talvez mesmo dentro da redação do Correio da Manhã, Pedro Correia de Araújo tomou novamente a defesa da arte moderna em junho de 1936. Apenas dois dias depois de Carlos Maul denunciar "o espírito subversivo do modernismo", o artista contra-atacou com um artigo enaltecendo "O vigor da Arte Moderna", grafando o termo com iniciais maiúsculas, de modo pouco usual para os padrões do jornal. ${ }^{69} \mathrm{O}$ artigo é uma tentativa evidente de salvar algo do edifício modernista dos escombros em que ruiu após o terremoto de novembro de 1935. Assemelhando-se ao personagem Theodoro, de sua criação, Correia de Araújo tenta se posicionar fora e acima do confronto, lamentando a falta de crítica especializada e "a confusão dos nossos conceitos a respeito de arte". Todo o furor em torno da arte moderna não passaria, segundo ele, de um equívoco quanto ao entendimento da ideia de modernismo. "Toda a arte, na sua criação, é moderníssima," salienta, admitindo existirem "ignorantes" inscritos também no campo modernista e concedendo, até mesmo, que o "programa das esquerdas (...) visa evidentemente destruir a civilização clássica tradicional". Porém, rebate ele, Cézanne, Picasso e Diego Rivera não são "subversivos"; antes, são restauradores, reatando as "razões plásticas" da tradição. Em argumentação tortuosa, Correia de Araújo acusa tanto os tais ignorantes quanto os passadistas de serem os verdadeiros subversivos, por estarem "fora da vida". A "cidadela sonolenta da Escola Nacional de Belas Artes" precisa ser sacudida, e ele espera que o novo Plano Nacional de Educação - cuja discussão teve início em janeiro de 1936 - o faça. ${ }^{70}$ Quase não precisa dizer que sua posição soa tímida e temerosa, no rebuscamento de seus raciocínios, em comparação com a truculência verbal de Maul.

A partir de meados de 1936, a cobertura de arte moderna no Correio da Manhã entra em fase de declínio gradual. Há ainda faíscas de entusiasmo, como uma entrevista com o escultor Ernesto de Fiori em que ele afirma: "Modernismo era um termo que já andava muito desmoralizado. Essa desmoralização porém é natural. Não significa que tenha fracassado o movi-

\footnotetext{
${ }^{69}$ ARAÚJO, Pedro Correia de. O vigor da Arte Moderna. Correio da Manhã, Rio de Janeiro, 27/06/1936, p. 2.

${ }^{70}$ Sobre o Plano Nacional de Educação, ver SCHWARTZMAN, BOMENY \& COSTA, op. cit., p. 192-204.
} 
mento de renovação."71 Dado o contexto, o advérbio "já" só pode remeter ao movimento subversivo do ano anterior e às represálias contra ele. O termo modernismo "já" andava desmoralizado, insinuam as entrelinhas do texto, mesmo antes que a febre anticomunista levasse ao fechamento do Clube de Cultura Moderna, à demissão de professores da UDF e banisse o assunto da pauta do jornal. Essa faísca acende um fogo de palha. O insistente Pedro Correia de Araújo volta à tona em meados de 1937, com outra contribuição do enigmático Theodoro, dessa vez em matéria que traz como sub-lead a sentença: "a destruição da arte pelos passadistas".72 Já não convence muito a acusação lançada por Theodoro de que ambos, Anargono e Fotofil, são uns preguiçosos. Preguiça deve ter tido o leitor do suplemento de domingo de acompanhar elucubrações tão rebuscadas para defender uma posição que, até bem pouco, era simples e clara: a favor da arte social. Somente a movimentação em torno da campanha eleitoral para a presidência foi capaz de resgatar o modernismo do marasmo dominical e devolvê-lo para as páginas principais do jornal. Em artigo elogiando o candidato da situação, José Américo de Almeida, o advogado alagoano Povina Cavalcanti traça a seguinte análise do movimento de 1922:

Vivia-se, então, numa enervante pasmaceira no mundo das letras. S. Paulo esgotava os últimos pruridos de inovação com os remanescentes de uma frustrada Semana de Arte Moderna. No fundo desse movimento, era fácil descobrir-se o objetivo nativista dos bandeirantes: conquistar para a Pauliceia a centralização do comando espiritual das letras brasileiras, que sempre teve sede na metrópole. Não vingou o intento. ${ }^{73}$

Bom sobrevivente político, conforme demonstraria ao longo da vida, Povina disseca secamente a derrota do projeto modernista/tenentista. Da perspectiva de meados de 1937, o viés descendente do movimento era nítido: à derrota de São Paulo na Revolução Constitucionalista vinha se somar a virtual liquidação das forças de esquerda em 1935. A guinada à direita pavimentava o caminho para um fortalecimento ainda maior do poder central, e Povina fazia sua aposta em José Américo como opção preferível a Plínio Salgado, então em plena ilusão de que viria a ocupar a presidência. Mal

\footnotetext{
${ }^{71}$ FIRMEZA, Mozart. Ernesto de Fiori, o escultor da substância. Correio da Manhã, Rio de Janeiro, 06/12/1936, suplemento, p. 2.

${ }^{72}$ ARAÚJO, Pedro Correia de. Contribuição de Theodoro às belas artes. Correio da Manhã, Rio de Janeiro, 09/05/1937, suplemento, p. 4.

${ }^{73}$ CAVALCANTI, Povina. A força de um símbolo. Correio da Manhã , Rio de Janeiro, 22/07/1937, p. 2.
} 
sabiam eles que o verdadeiro beneficiário do endurecimento não seria nem um, nem outro, mas a continuação do governo Vargas garantida pelo golpe do Estado Novo.

Entre meados de 1937 e meados de 1939, o assunto da "arte moderna" some praticamente das páginas do Correio da Manhã. Alguns partidários do modernismo ainda tentavam introduzi-lo, de vez em quando, de modo enviesado. Por ocasião de visita às obras do novo edifício da ABI - projetado em estilo modernista por Marcello e Milton Roberto - Celso Kelly, agora na condição de presidente da Associação dos Artistas Brasileiros, fez publicar uma carta de felicitações a Herbert Moses, presidente da ABI, destacando sua "esplêndida impressão" de inovações como o uso de brise-soleils na fachada. ${ }^{74}$ Dados os fortes interesses que ligavam Paulo Filho e Costa Rego à ABI, o fato era mais do que relevante para inclusão no Correio da Manhã. Quatro dias depois da publicação dessa matéria, a esplêndida impressão de Kelly é desfeita, aos olhos do leitor atento, por uma análise das relações entre arquitetura moderna e propaganda comunista, intitulado "Arquitetura marxista", curto e grosso. ${ }^{75}$ No clima de caça às bruxas do Estado Novo, já não havia mais espaço para a militância modernista promovida durante anos a fio por um J. Cordeiro de Azeredo, sem contrabalançar com uma dose sólida de anticomunismo.

Assim, a arte moderna, assunto de tão vivo interesse jornalístico durante treze anos, definhava na asfixia em decorrência do forte patrulhamento ideológico imposto após novembro de 1937. Mesmo existindo correntes modernistas alinhadas tanto com o comunismo quanto com o integralismo, o fato é que ambas as tendências foram proscritas pelo novo regime. Nesse período de endurecimento do Estado Novo, foram capazes de sobreviver somente os modernistas dotados de discrição ou maleabilidade suficientes para navegarem entre as rochas gêmeas de esquerda e direita, ou então aqueles cujo desinteresse profundo por ideologias os colocava a salvo. Tratase, essencialmente, de dois grupos: aqueles que se abrigaram sob o prestígio de Capanema, no Ministério da Educação e Saúde, ou então os que mantiveram distância das intrigas do Distrito Federal.

\footnotetext{
${ }^{74}$ Olhando a casa do jornalista. Correio da Manhã, Rio de Janeiro, 24/06/1938, p. 3. Celso Kelly foi integrante do júri que escolheu o projeto dos irmãos Roberto e sucederia Herbert Moses na presidência da ABI, em 1964.

75 SOUZA, O. de Carvalho. Arquitetura marxista. Correio da Manhã, Rio de Janeiro, 28/06/1938, p. 4.
} 


\section{Conclusões}

A partir de uma análise da recepção pelo Correio da Manhã, faz-se possível extrair tendências sobre a ascensão da arte moderna entre 1922 e 1945 que divergem do senso comum. Primeiramente, constata-se que essa trajetória não foi nem linear, nem uniforme e nem mesmo necessariamente ascendente do ponto de vista dos atores que a vivenciaram. Reforça-se, portanto, a tese de que o triunfo do modernismo de 1922 é um constructo historiográfico, imposto ao material histórico por sua releitura posterior entre as décadas de 1940 e 1970. Em segundo lugar, constata-se uma correlação forte entre a presença de arte moderna no jornal e o contexto político imediato. Em dois momentos de agitação aguda - o período em torno da Revolução Constitucionalista de 1932 e os dois anos que se seguiram ao golpe do Estado Novo em 1937 - ocorreu diminuição sensível na cobertura, chegando à quase ausência do tema. Se esse arrefecimento foi fruto de censura, autocensura ou desinteresse é questão que permanece em aberto. Num terceiro momento - nomeadamente a crise em torno da sublevação militar de 1935 - o modernismo artístico é alçado a questão editorial premente e vira alvo de ataques anticomunistas incensados.

A terceira conclusão surpreendente diz respeito à liderança e à unidade do movimento. A leitura do Correio da Manhã evidencia a disputa entre Oswald de Andrade e Graça Aranha, no período entre 1924 e 1931, com nítida vantagem para o último. Pelo menos no Rio de Janeiro, então Distrito Federal, Graça Aranha foi percebido como principal liderança do movimento. Mário de Andrade, geralmente tido como mentor indiscutível do modernismo brasileiro, ocupava patamar bem inferior a esses dois na cobertura do jornal. Pela ótica do Correio da Manhãa, se é que existiu nesse período um foco unificado do movimento modernista, este girava em torno da figura de Graça Aranha. Após sua morte em 1931, não ocorre um aumento correspondente do espaço atribuído a Oswald ou Mário de Andrade. Ao contrário, a arte moderna entra num período em que se torna propriedade de muitos, e não feudo de um ou de outro, com uma inclinação marcada em favor do engajamento social e político.

A quarta conclusão diz respeito justamente à consolidação de um meio mais amplo que acolhe e promove a arte moderna. Entre o final de 1932 e meados de 1935, a cobertura do Correio da Manhã revela a existência de uma rede ativa de sociabilidade e intercâmbio em torno da Fundação Graça Aranha e do Clube de Cultura Moderna - com ramificações para a Sociedade Pró-Arte e Associação dos Artistas Brasileiros - organizações pouco 
estudadas cujas atividades são ainda menos conhecidas do que as de suas correspondentes paulistas Spam e CAM. Dada a proeminência conquistada por essas entidades na cobertura do jornal, sua estrutura merece maiores pesquisas do que as que têm surtido até hoje. A relação entre o Clube de Cultura Moderna, alvejado por Carlos Maul em seus ataques anticomunistas, e o Instituto de Artes da UDF também salta aos olhos como assunto digno de investigação aprofundada. Evidencia-se na figura do artista e crítico Pedro Correia de Araújo um elo entre as duas instituições e o jornal.

A polarização ideológica ocorrida a partir dos acontecimentos de novembro de 1935 talvez constitua o achado mais revelador da pesquisa presente. O modo como "arte moderna" e "modernismo" são implicados diretamente na fúria anticomunista expressa por Carlos Maul é fato muito significativo, que pede um levantamento em outras fontes da mesma época para averiguar até que ponto foi peculiar a esse autor. A associação entre modernismo e comunismo não era inevitável, e muito menos universal, no momento em que se atribui peso editorial a ela no Correio da Manhã. O expurgo de professores ocorrido na UDF, logo em seguida, sugere um clima de caça às bruxas que talvez explique a relutância subsequente do jornal em abrir espaço para a arte moderna. Ambos os fatos são indicativos de uma radicalização política do meio modernista, que passa a se dividir entre os polos de integralismo/nacionalismo, de um lado, e comunismo/cosmopolitismo, do outro. A constatação desse choque de ideologias torna-se ainda mais significativo em função da diminuição relativa no caráter contestatório da arte moderna, após 1937, quando muitos integrantes do movimento foram cooptados para o projeto estatizante. Na hipótese de que a cobertura do Correio da Manhã seja reflexo de tendências mais amplas, não dá para presumir uma continuidade simples entre as aspirações de 1922 e os rumos do modernismo após 1945. 